Vol. 1, No. 2, Juli - Desember 2017

\title{
eäureligia
}

\section{PEMIKIRAN PENDIDIKAN ISLAM KH. ABDURRAHMAN \\ WAHID DAN IMPLIKASINYA BAGI PENGEMBANGAN PENDIDIKAN ISLAM DI INDONESIA}

\author{
Moch. Tohet \\ Fakultas Tarbiyah Institut Agama Islam Nurul Jadid, Indonesia
}

\section{Info Artikel}

Sejarah Artikel:

Diterima Juni 2017

Disetujui Juli 2017

Dipublikasikan Oktober 2017

Keywords:

Abdurrahman Wahid;

Pendidikan Islam;Keislaman

\begin{abstract}
Abstrak
Pendidikan merupakan proses budaya untuk meningkatkan harkat dan martabat manusia yang berlangsung sepanjang hayat. Pendidikan selalu berkembang dan selalu dihadapkan pada perubahan zaman. Untuk itu, mau tak mau pendidikan harus didesain mengikuti irama perubahan tersebut. Apabila pendidikan tidak didesain mengikuti irama perubahan, maka pendidikan akan ketinggalan laju perkembangan zaman itu sendiri. Pendidikan Islam dalam pandangan $\mathrm{KH}$. Abdurrahman Wahid haruslah menjadi pangkalan untuk merebut kembali wilayah-wilayah yang kini sudah mulai lepas. Ia menjadi tumpuan langkah strategis untuk membalik arus yang menggedor pintu pertahanan umat Islam. Sesuatu yang cukup vital adalah membuat sebuah kerangka pemahaman, khususnya dalam pendidikan Islam sehingga mampu menjadi inspirasi dalam mengamalkan ajaran-ajaran Islam yang sifatnya universal. Pemahaman terhadap nilai-nilai ajaran Islam pun menjadi pemahaman yang utuh dan komprehensif
\end{abstract}

Alamat Korespondensi:

Gedung E Lantai 1 Fakultas Agama Islam

PO. Box 1 Paiton Probolinggo, 67291

E-mail: elheds78@gmail.com
ISSN 2549-4821

E-ISSN 2579-5694 


\section{PENDAHULUAN}

Seiring dengan zaman yang sudah modern ini, pendidikan masih dianggap sebagai kunci pembuka dalam komunitas sosial untuk mengimbangi laju berkembangnya ilmu dan teknologi. Persepsi masyarakat ini kiranya telah mampu memobilisasi kaum cerdik cendikia untuk selalu merespon secara stimulan terhadap perkembangan dan sistem pendidikan berikut unsur-unsur terkait yang berpotensi positif bagi keberhasilan pendidikan.1 Hal ini disadari karena, pendidikan merupakan perkara penting dalam membangun sebuah negeri. Sebagaimana yang diungkapkan oleh Sayyid Ahmad Khan, bahwa kemajuan suatu bangsa tergantung pada pendidikannya. 2

Pendidikan adalah proses budaya untuk meningkatkan harkat dan martabat manusia yang berlangsung sepanjang hayat. Pendidikan selalu berkembang dan selalu dihadapkan pada perubahan zaman. Untuk itu, mau tak mau pendidikan harus didesain mengikuti irama perubahan tersebut. Apabila pendidikan tidak didesain mengikuti irama perubahan, maka pendidikan akan ketinggalan laju perkembangan zaman itu sendiri.

Dalam pandangan filsafat Islam, sebagaimana ditegaskan dalam al-Qur'an, bahwa pada hakikatnya manusia adalah khalifah Allah di alam semesta ini.3 Dalam statusnya sebagai khalifah ini, berarti manusia hidup di alam mendapat kuasa dari Allah untuk mewakili dan sekaligus sebagai pelaksana dari peran dan fungsi Allah di alam. Di antara peran dan fungsi utamanya adalah sebagai "rabb alalam", yaitu mendidik dalam arti mengarahkan pertumbuhan dan perkembangan alam (termasuk manusia sebagai bagian dari alam). Ini adalah salah satu tugas manusia sebagai khalifah, yang harus diemban dengan penuh ketaatan dan penuh tanggung jawab. Dengan demikian, manusia sebagai bagian dari alam, memiliki potensi untuk tumbuh dan berkembang bersama alam lingkungannya. Tetapi sebagai khalifah Allah, maka manusia mempunyai tugas

1 A. Malik Fadjar, Holistika Pemikiran Pendidikan, Jakarta: RajaGrafindo Persada, 2005), v.

2 Hanun Asrohah, Sejarab Pendidikan Islam, (Jakarta: Logos Wacana Ilmu, 2001), 136. untuk memadukan pertumbuhan dan perkembangannya bersama dengan alam. Sebagai khalifah Allah, maka manusia bertugas dan diberi kuasa oleh Allah untuk mengembangkan diri dalam dan bersama lingkungannya, memelihara dan mengarahkan pada kehidupannya yang Islami.4

Untuk mendesain pendidikan Islam yang ideal tentunya diperlukan kajian-kajian yang intensif dan mendalam baik melalui studi historis maupun penelitian-penelitian. Dari kajian historis kita akan mendapatkan banyak percikan pemikiran-pemikiran tokoh, baik mereka yang mengatasnamakan diri sebagai praktisi pendidikan, ataupun secara implisit mereka memiliki kapasitas yang tidak kalah mumpuni dengan para tokoh pendidikan tersebut.

KH. Abdurrahaman Wahid atau lebih akrab dikenal dengan sebutan Gus Dur, adalah salah satu tokoh nasional yang mempunyai konstribusi yang sangat besar untuk meningkatkan harkat manusia, khususnya bagi bangsa Indonesia melalui perjuangan demokrasi, partisipasi politik maupun dalam bidang pendidikan, secara khusus pendidikan Islam.

Yang menarik dari KH. Abdurrahman Wahid sehingga diangkat dalam sebuah penelitian setingkat tesis ini adalah, karena pada diri $\mathrm{KH}$. Abdurrahman Wahid melekat berbagai predikat, yakni kiai, politisi, intlektual, pendidik, budayawan, mantan pimpinan organisiasi massa terbesar di Indonesia, mantan tokoh pergerakan, dan mantan presiden RI. Ini tentu cukup menyulitkan bagi mereka yang ingin mendalami pemikiran dan gagasannya.

Kesulitan untuk menempatkan $\mathrm{KH}$. Abdurrahman Wahid sebagai tokoh modernis Islam, karena terkadang ia banyak melakukan hal-hal yang berada di luar koridor logika yang rasional. Sebagai seorang ilmuwan yang banyak memahami pemikiran modern dari Barat yang sekuler dan liberal, ternyata ia juga begitu taat kepada pendapat dan nasihat para kiai senior atau kiai sepuh, menziarahi tempat-tempat dan orang-orang yang dianggapnya dapat memberikan dukungan spiritual dan lain sebagainya. Namun demikian, dalam waktu yang bersamaan ia juga tidak dapat dikatakan tradisionalis konservatif, karena terkadang ia melontarkan gagasan dan pemikiran yang selamanya tidak selalu sejalan dengan pendapat

\footnotetext{
An'am (6): 165

4 Zuhairini, dkk, Filsafat Pendidikan Islam, (Jakarta: Bumi Aksara, cet. IV, 2008), 121-122
}

${ }^{3}$ Lihat surat Al-Baqarah (2): 30 dan Al- 
kebanyakan dari kalangan ulama tradisionalis yang berpegang teguh kepada kitab-kitab rujukan dari imam mazhab yang empat (Hanafi, Maliki, Syafi'i, dan Hambali). Barangkali tepatnya ia dikatakan sebagai tokoh Islam yang modernis dan liberalis yang unik. Keunikannya itu terletak pada sikapnya yang terkadang begitu kuat berpegang pada fatwa ulama sepuh dan hal-hal lain yang berada di luar koridor dan paradigma sikap-sikap sebagai seorang yang modern. Lebih tepatnya lagi, ia pantas dikatakan sebagai tokoh Islam yang unik dan kontroversial.5

Kesulitan untuk memahami $\mathrm{KH}$. Abdurrahman Wahid secara utuh juga diakui oleh Greg Barton.6 Kesulitan atau lebih tepatnya kebingungan itu berasal dari fakta bahwa pada satu sisi $\mathrm{KH}$. Abdurrahman Wahid dipandang dan dikenal banyak orang sebagai figur religius, dan pada sisi yang lain ditafsirkan oleh banyak orang, khususnya di pusatpusat metropolitan dan antara kelas menengah terdidik Indonesia sebagai politisi yang sekuler atau sebagai intelektual yang liberal. Dengan alasan kedua ini, kesalahpahaman tentang $\mathrm{KH}$. Abdurrahman Wahid berjalan seiring dengan kesalahpahaman tentang Barat pada umumnya, yaitu bagaimana seseorang yang merupakan intelektual liberal juga dapat dianggap sebagai figur

5 Abuddin Nata, Tokoh-tokoh Pembaruan Pendidikan Islam di Indonesia, (Jakarta: RajaGrafindo Persada, 2005), 344-345.

${ }^{6}$ Greg Barton adalah pengajar mata kuliah Religious and Asian Studies di Deakin University. Disertasinya diraih pada tahun 1995 mengenai pemikiran neo-modernisme empat cendikiawan muslim Indonesia, yaitu Djohan Efendi, Ahmad Wahib, Nurcholish Madjid dan Abdurrahman Wahid. Bersama Greg Fealy ia menyunting buku Tradisionalisme Radikal: Persingoungan Nahdatul Ulama-Negara (edisi Indonesia), yang diterbitkan oleh LKiS, Yogyakarta, 1997, yang berisi tulisan tujuh pengamat asing mengenai NU dan pesantren.

7 Pengantar Greg Barton dalam KH. Abdurrahman Wahid, Prisma Pemikiran Gus Dur, (Yogyakarta: LKiS, 2010), xxii.

8 Lihat UU RI nomor 20 tahun 2003 tentang Sistem Pendidikan Nasional, dalam Kumpulan Undang-Undang dan Peraturan Pemerintah RI Tentang Pendidikan, Jakarta: Direktorat Jenderal Pendidikan Islam Departemen Agama RI, 2007), 8. religius dan bahkan pemimpin karismatik setingkat wali. 7

Di antara implikasi pemikirannya adalah perjuangannya yang tiada henti terhadap pendidikan Islam, melalui upaya membuka kran kesederajatan warga secara manusiawi, dengan menempatkan sosok manusia dalam hal ini adalah warga negara Indonesia sejajar di hadapan hukum dan negara. Eksesnya adalah masuknya nilai-nilai pendidikan Islam secara deras dalam konstitusi negara. Indikasinya adalah, lahirnya Undang-undang nomor 20 tahun 2003 tentang Sistem Pendidikan Nasional, melalui proses penyadaran secara struktural pada saat Gus Dur menjabat sebagai presiden, dan baru diundangkan pada tahun 2003, pada saat Megawati Soekarno Putri menjabat sebagai presiden. Di dalamnya, mulai disebutkan dengan tegas urgensitas pendidikan agama, dengan menampilkan sosok idealitas dalam sebuah pola pembentukan kepribadian dalam proses pendidikan, yaitu pasal 3 UU Republik Indonesia nomor 20 Tahun 2003 tentang Sistem Pendidikan Nasional.8

\section{BIOGRAFI KH. ABDURRAHMAN WAHID}

\section{Riwayat Hidup}

Abdurrahman Wahid yang akrab dipanggil Gus9 Dur, dengan nama lengkap Abdurrahman alDakhil,10 lahir pada tanggal 4 Agustus 1940, di Denanyar, Jombang, Jawa Timur, di rumah pesantren milik kakek dari pihak ibunya, Kiai Bisri Syansuri.11 Ia adalah putra pertama dari

9 Gus adalah kependekan dari Bagus, sebuah sebutan yang biasa digunakan untuk anak seorang kiai di Jawa Timur dan Jawa Tengah. Nama tersebut mengandung harapan agar anaknya menjadi orang yang baik. Panggilan ini biasanya digunakan untuk anak sebelum kelak dewasa menjadi seorang kiai.

10 Abdurrahman al-Dakhil dalam bahasa Indonesia berarti "hamba Allah (Penyayang), Sang Penakluk." Penamaan Abdurrahman al-Dakhil dinisbahkan kepada seseorang yang pernah memegang kekuasaan selama 32 tahun, dari tahun 756-788 H. di Spanyol. Abdurrahman al-Dakhil dalam sejarah Spanyol adalah seorang pelarian yang menyeberangi dataran tandus dan bukit batu memasuki negeri sebagai orang asing yang tersisih. Namun, ia kemudian berhasil membangun kekuasaan, kemakmuran negeri, menyusun tentara dan mengatur pemerintahan.. Lihat Tim INCRes, Beyond the Symbol: Jejak Antropologis Pemikiran dan Gerakan Gus Dur, (Bandung: Remaja Rosdakarya, 2000), 26

11 Greg Barton, Biografi Gus Dur, The Authorized Biography of Abdurrabman Wabid, (Yogyakarta: LKiS, cet IX, 2010), 25-26 
enam bersaudara. Ayahnya bernama Wahid Hasyim, adalah putra KH. Hasyim Asy'ari, pendiri pondok pesantren Tebuireng dan pendiri Nahdatul Ulama (NU)12, organisasi massa terbesar di Indonesia. Ibunya bernama Hj. Solichah, juga putri tokoh besar Nahdatul Ulama (NU), KH. Bisri Syansuri, pendiri pondok pesantren Denanyar Jombang dan Ro'is Am Syuriah Pengurus Besar Nahdatul Ulama (PBNU) setelah KH. Abdul Wahab Chasbullah.13

Baik dari keturunan ayah maupun ibunya, Abdurrahman Wahid adalah sosok yang menempati strata sosial tertinggi dalam masyarakat Indonesia. Ia adalah cucu dari dua ulama terkemuka Nahdatul Ulama (NU) dan tokoh terbesar bangsa Indonesia. Kakeknya, KH. Bisri Syansuri dan KH. Hasyim Asy'ari sangat dihormati di kalangan NU, baik karena perannya sebagai pendiri Nahdatul Ulama (NU), maupun karena kedudukannya sebagai ulama kharismatik.14

Faktor geneologis ini ternyata sangat memengaruhi sikap dan karakter Gus Dur. Keberanian dan prinsip dalam memperjuangkan demokrasi, hak asasi manusia (HAM) dan pluralisme, ini diakui oleh banyak kalangan. Sekalipun banyak kalangan yang berbicara tentang hal yang serupa, tetapi, menurut Muslim Abdurrahman Gus Dur lah yang menjadi pionirnya. 15

Gus Dur menikah dengan Nuriyah, putri H. Abdullah Syukur, pedagang terkenal dari Jombang, pada tanggal 11 September 1971, dan dikaruniai empat orang putri, Allisa Qarunnada Munawwaroh,

12 Organisasi massa Islam terbesar di Indonesia ini didirikan pada tanggal 31 Januari 1926 di Surabaya. Dan sebagai inspiratornya adalah KH. Hasyim Asy'ari, yang kemudian menjadi ro'is akbar, yang artinya pemimpin agung. Beliau juga bergelar hadratus syeikh, yang artinya guru agung, sebuah gelar kehormatan yang jarang diberikan kepada orang lain. Organisasi ini lahir sebagai reaksi atas berkuasanya pemimpin Wahabi di Makkah yang dipelopori oleh Ibnu Sa'ud, yang khawatir kalau-kalau Ibnu Sa'ud yang reformis itu akan membatasi pengamalan keagamaan kaum Islam tradisionalis, khususnya di Indonesia, yang mayoritas pemeluknya menganut Islam Ahlus Sunnah Wal Jama'ah, penganut mazhab Syafi'i, yang antara lain membiarkan terjadinya pencemaran di makam-makam orang suci,
Zannuba Arifah Chafsoh, Anita Hayatunnufus, dan Inayah Wulandari.

Gus Dur meninggal pada tanggal 30 Desember 2009, di rumah sakit Cipto Mangunkusumo (RSCM) Jakarta, dalam usia 69 tahun, dan dimakamkan di komplek pemakaman keluarga pondok pesantren Tebuireng Jombang, Jawa Timur.16

\section{Pendidikan}

\section{Pendidikan di dalam negeri}

Sekalipun secara geneologis menempati strata sosial yang tinggi, tetapi sejarah kehidupan Gus Dur tidak mencerminkan kehidupan yang ningrat. Dia berproses dan hidup sebagaimana layaknya masyarakat kebanyakan di mana dia belajar di pesantren.

Mula-mula ia belajar mengaji dan membaca alQur'an dari kekeknya, KH. Hasyim Asy'ari, di pesantren Tebuireng, Jombang, Jawa Timur. Ia mendapat pendidikan sekolah dari ayahnya, tetapi sebagaimana pelajar madrasah lainnya, ia pertama-tama belajar membaca dan menulis dalam tulisan Arab. KH. Wahid Hasyim lantas mengajarinya membaca huruf latin serta bahasa yang merupakan alat percakapan orang Belanda dan orang Indonesia, yaitu bahasa Melayu lokal.

Pendidikan formalnya dimulai dari Sekolah Dasar KRIS di Jakarta Pusat, tetapi setelah memasuki kelas empat, ia pindah sekolah yang berada di dekat rumah tinggalnya. Kedua sekolah ini adalah sekolah biasa untuk ukuran seorang putera menteri.

Setelah lulus dari sekolah dasar, ia melanjutkan pendidikannya ke Sekolah Menengah Ekonomi Pertama (SMEP). Namun karena masih dihinggapi perasaan sedih karena ditinggal ayahnya, dia sempat mengulang pada saat kelas satu, walaupun sebenarnya ia pandai, tetapi pada

yang dianggap sakral oleh orang Islam penganut mazhad Syafi'i. Lihat Greg Fearly, Ijtihad Politik Ulama, Sejarah NU 1952-1967, (Yogyakarta: LKiS, 1998), 32

13 Abuddin Nata (editor), Tokoh-tokoh Pembaruan Pendidikan Islam di Indonesia, Jakarta: RajaGrafindo Persada, 2005), 338-339

14 Abuddin Nata (editor), Tokoh-tokoh Pembaruan..........., 339

15 Irwan Suhanda (editor), Gus Dur Santri Par Excellence Teladan Sang Guru Bangsa, Jakarta: PT Kompas Media Nusantara, 2010), 22

${ }^{16}$ Ia meninggal karena komplikasi berbagai penyakit yang dideritanya, dan bukan karena adanya percobaan pembunuhan, sebagaimana isu yang beredar waktu itu. Hal ini disampaikan oleh juru bicara pihak keluarga, dr. Umar Wahid, yang juga adik kandungnya, yang disiarkan oleh berbagai media massa sesaat setelah wafatnya. 
saat yang sama ia cenderung malas. Waktunya dihabiskan untuk membaca buku dan menonton sepak bola, karena dirasa pelajaran di sekolah kurang menantang.

Setelah tamat SMEP, pada tahun 1957 Gus Dur mengikuti pelajaran penuh di pesantren Tegalrejo, Magelang yang terletak di sebelah utara kota Yogyakarta yang diasuh oleh kiai Khudori. Pada saat yang bersamaan, ia juga belajar paro waktu di pesantren Denanyar Jombang yang diasuh oleh kakeknya sendiri, $\mathrm{KH}$. Bisri Syansuri. Gus Dur hanya butuh waktu dua tahun untuk menyelesaikan pelajarannya, atau dua tahun lebih cepat dari waktu normal, bahkan sebagian besar waktunya dihabiskan di luar kelas untuk membaca buku-buku Barat.

Bahkan, sejak duduk di bangku SMEP inilah minat baca terutama buku-buku dan majalah-majalah yang seharusnya menjadi konsumsi orang-orang yang usianya beberapa tahun di atasnya telah dibaca.17

Ketika tinggal di Yogyakarta, ia mulai menyukai film secara serius. Hampir sebagian besar waktunya selama tinggal di kota ini dihabiskan untuk menonton film. Hal ini tentu bukan perilaku yang diharapkan dari seseorang yang akan mengikuti jejak sejumlah pemimpin agama yang paling dihormati di Indonesia. Walaupun kemudian Gus Dur mengembangkan apresiasi yang serius mengenai film, pada tahap ini ia menonton saja apa yang dapat ditonton di Yogyakarta. Meskipun demikian, sebagai seorang remaja yang sangat menggandrungi film, apresiasi Gus Dur terhadap film jauh lebih serius daripada yang ditunjukkan oleh kebanyakan teman-teman sebayanya.18

Di Yogyakarta juga Gus Dur pertama-tama mulai tertarik pada wayang kulit, yang merupakan pertunjukan wayang tradisional. Pertunjukan wayang kulit ini sering diadakan di sekitar Yogyakarta, tetapi jarang dipentaskan di ibu kota. Ketika berdiam di Yogyakarta dan Magelang, ia selalu mencari-cari pertunjukan wayang kulit dan umumnya ia bisa menonton pertunjukan ini setiap dua minggu atau tiga minggu sekali, walaupun untuk itu ia harus menempuh jarak yang cukup jauh.

Sebagaimana juga remaja lainnya, ia juga menyukai sastra picisan. Baginya bacaan ini sering mengandung unsur penting dalam hidupnya. Di kota ini juga, dia juga banyak menghabiskan waktunya untuk membaca karya sastra, termasuk cerita-cerita silat yang menceritakan pendekar-pendekar Cina yang kaya akan falsafah itu.

Bagian ini penting untuk disampaikan, karena kelak turut mewarnai satu dari beberapa bagian dalam diri Gus Dur, sebagai seorang budayawan yang kaya akan filosofi hidup dan joke-joke segar, yang diiringi keberanian sikap19 untuk mewujudkan filosofi tersebut dalam kehidupan nyata.

Pada tahun 1959, Gus Dur pindah ke Jombang untuk belajar secara penuh di pesantren Tambak Beras di bawah asuhan KH. Wahab Chasbullah. Di sana ia belajar sampai tahun 1963.

\section{Pendidikan di luar negeri}

Pada tahun yang sama, 1963, ia melanjutkan studinya ke Universitas al-Azhar Kairo, Mesir, tepatnya di Department of Higher Islamic and Arabic Studies, karena mendapatkan beasiswa dari Departemen Agama. Namun pada akhirnya
17 Salahuddin Wahid, "Gus Dur ..............., 34 .

18 Greg Barton, Biografi 19.........., 54 Telah dibuktikan melalui perannya dengan mendirikan LSM yang bergerak dalam bidang demokrasi, yaitu FORDEM (Forum Demokrasi) yang didirikan pada bulam Maret 1991, yang telah banyak membentuk kaum minoritas dan mereka yang termarginalkan. Ini dibuktikan dengan upayanya untuk memperjuangkan komunitas Tionghoa, untuk memperoleh haknya, hingga pembelaannya terhadap Inul Daratista yang dianggap mencederai nilai seni yang sesungguhnya, serta Ulil Absar Abdallah yang dituding telah melenceng dan sesat. Dalam karir politiknya, keberanian itu ditujukkannya ketika dia menjadi presiden, dengan mengganti Wiranto sebagai panglima ABRI, yang mempunyai massa pendukung di kalangan militer, termasuk waktu itu fraksi TNI/POLRI yang ada di DPR, yang pada akhirnya menjadi penentu kejatuhannya dari kursi presiden. Baca Mahfud MD, Setahun Bersama Gus Dur .........., terutama halaman 94 tentang pemberhentian Wiranto. Di samping itu, prestasi lainnya adalah menerbitkan Keppres no. 6 tahun 2000 tentang pencabutan Instruksi Presiden nomor 14 tahun 1967 tentang agama, kepercayaan, dan adat istiadat Cina, yang berakibat terhadap pengakuan Konghuchu sebagai agama yang boleh diajarkan di Indonesia, serta pengakuan akan hak dan martabat kaum etnis Tionghoa. 
ia tidak tamat.20 Ia kecewa karena perlakuan kampus yang memasukannya di kelas pemula, bersama para calon mahasiswa yang belum mempunyai pengetahuan tentang bahasa Arab, bahkan ada yang sama sekali tidak tahu abjad Arab, apalagi menggunakannya dalam percakapan. Karena rasa kecewa atas perlakuan ini, hampir sepanjang tahun 1964 ia tidak masuk kelas, ujung-ujungnya gagal naik kelas karena waktunya banyak dihabiskan untuk nonton bioskop, sepak bola dan mengunjungi perpustakaan terutama perpustakaan American University Library- serta waktunya habis di kedai-kedai kopi untuk diskusi. Keberadaannya di universitas al-Azhar merupakan suatu kekecewaan baginya, namun sebaliknya kota Kairo baginya sangat memesona dan menyenangkan. Kota Kairo banyak memberikan kebebasan berpikir dan dari al-Azharlah Muhammad Abduh, seorang perintis gerakan modernisme Islam yang progresif berasal. 21

Selama di Kairo, karakter intelektualitasnya terbangun secara liberal. Ini disebabkan menu yang menjadi konsumsi bacaannya adalah buku-buku yang menggemparkan saat itu, seperti alIslam wa Ushul al-Hukm karangan Syekh Ali Abdurrazeq, yang dianggap membawa paham sekuler karena membenarkan pemisahan agama dan negara, dan buku Aqidah wa Syari'ah tulisan Dr. Abdul Halim Nggar, serta buku Wilayat al-Faqih karangan Imam Khumaini. Sehingga tidak jarang ide-idenya muncul secara kontroversial.22

Dari Kairo, ia pindah ke Baghdad, Irak pada tahun 1970 dengan mengambil

${ }^{20}$ Irwan Suhanda (editor), Gus Dur Santri Par Excellence............... xv

${ }^{21}$ Greg Barton, Biografi............, 84

22 Musthafa Abd. Rahman, "Gus Dur Agama dan Negara”, dalam Gus Dur Santri Par Excellence, ............, 121-122

23 Abuddin Nata (editor), Tokohtokoh Pembaruan......................, 343

24 Damien Dematra, Sejuta Hati Untuk Gus Dur Sebuab Novel dan Memorial, (Jakarta: Gramedia Pustaka Utama, 2010), 217

${ }^{25}$ Mahfud MD, Setahun Bersama Gus Dur ....................., 183

${ }^{26}$ Kiai Khudori adalah sosok kiai yang humanis, saleh dan dicintai. Kiai Khudori inilah yang memperkenalkan Gus Dur dengan jurusan sastra di Universitas Baghdad. Selama belajar di Baghdad inilah, Gus Dur merasa puas dan telah menemukan apa yang sesuai dengan panggilan jiwanya. Di universitas inilah ia mengenal karya-karya tokoh terkemuka seperti Emil Durkheim. Bahkan selama di perpustakaan Universitas Baghdad inilah, ia menemukan informasi sejarah yang lengkap tentang Indonesia. Selain itu, ia juga berkesempatan membaca karya-karya sastra dan budaya Arab serta filsafat dan pikiran sosial Eropa.23

Di Baghdad ini pula, dia mulai rajin kuliah dan mulai mempelajari pelajaran Arab klasik dengan cara pandang yang lebih sistematis. Ia juga melakukan perjalanan spiritual dengan menziarahi makam-makam suci. Ia juga mendalami ajaran Imam Junaid al-Baghdadi, terutama mengenai meditasi sufinya. Di sinilah ia menemukan pencerahan dan merasakan berbagai sentuhan mistik yang kuat.24 Bahkan dalam memahami dan menganalisis persoalan dan berbagai tindakan yang dilakukan oleh Gus Dur, cenderung nyeleneh dan menggemaskan, mirip kisah para sufi, yang cenderung saleh dan lucu.25 Ini membuktikan, betapa kuat pengaruh sifat sufistik dalam dirinya, sebagaimana proses pendidikan yang diperoleh dari pesantren Tegalrejo yang diasuh oleh kiai Khudori,26 hingga riyadlah-riyadlah27 yang dilakukannya sewaktu di Baghdad.

Kebiasaan berziarah dan mengunjungi makam para kiai besar dan para wali dilanjutkannya ketika pulang ke Indonesia. Seperti ketika terpilih menjadi Presiden Gus Dur langsung berziarah ke makam kiai Mutamakkin di Pati, juga ketika hendak pergi ke Australia, dia berziarah ke makam Sunan Ngundung di Trowulan, Mojokerto. Ini dilakukannya dalam upaya untuk menghormati perjuangan mereka. Telepas apakah ada isyarat gaib atau tidak, yang jelas ia meyakini akan adanya hal yang gaib. 28

ritus-ritus sufi, dan menanamkan praktik-praktik ritual mistik. Di bawah bimbingan kiai ini pula, Gus Dur sering mengadakan ziarah ke kuburan-kuburan keramat para wali di Jawa.

27 Ritual-ritual tertentu dengan membaca bacaan-bacaan tertentu, atau dengan cara puasa dengan jumlah hari tertentu, untuk mendekatkan diri kepada Allah, melalui ijazah (wasilah) sang guru

28 Hal ini diakui oleh Mahfud MD.

Misalnya pasa suatu acara sarapan pagi bersama, Gus Dur banyak bercerita tentang masalah-masalah gaib. Satu diantaranya adalah pertemuannya dengan Mbah Hasyim dan Sunan Kalijaga yang katanya telah mengabarkan tentang akan terjadinya beberapa hal di Indonesia. Lihat Mahfud MD, Setabun Bersama Gus Dur .................., 185 
Dari Baghdad, Gus Dur meneruskan pengembaraan akademisnya ke sejumlah negara Eropa, dari satu universitas ke universitas lainnya, di antaranya Jerman dan Prancis. Dan terakhir ia tinggal di Belanda selama sekitar enam bulan, dan sempat mendirikan Perkumpulan Pelajar Muslim Indonesia dan Malaysia.

Gus Dur cukup menyadari akan kekecewaan diri atas kegagalan memperoleh ijazah, sekaligus ilmu yang harus dilalui dengan perjuangan yang luar biasa berat, dengan risiko menerima segala profesi, mulai dari tukang gergaji kayu hingga tukang petik anggur. Itu semua dilakukannya demi menuntaskan belajarnya.29 Tetapi pada akhirnya tetap saja ijazah sebagai tanda bukti telah lulus tidak didapatkannya. Sekalipun demikian, pengembaraan intelektualnya tidak bisa dikatakan gagal, sebab sekalipun ia lebih banyak belajar di luar bangku kuliah, namun ia pandai menyerap apa yang ada di dalam buku yang dibacanya kemudian merangkainya dengan berbagai hal yang didapatkannya dari luar.30

\section{Karya Ilmiah}

Dari studi biblografis yang dilakukan, ternyata ditemukan ada 493 buah tulisan Gus Dur sejak awal 1970-an hingga tahun 2000-an. Hingga akhir hayatnya tahun 2009, karena produktifitas tulisannya, bisa jadi telah lebih dari 600 tulisan. Karya ilmiah yang telah ditulis selama lebih dari dua dasawarsa itu diklasifikasikan ke dalam delapan bentuk tulisan, yakni tulisan dalam bentuk buku, terjemahan, kata pengantar buku, epilog buku, analogi buku, artikel, kolom, makalah, dan sebagainya.

Gus Dur telah dikenal ide dan gagasannya, di samping sikap nyelenehnya. Tetapi lebih dari itu, sebenarnya dia adalah seorang penulis yang produktif. Tetapi dari sekian banyak tulisannya, yang murni terkodifikasi dalam bentuk buku hanya beberapa buah saja. Hal ini terjadi karena minimnya waktu untuk konsentrasi menjadikan tulisannya dalam bentuk buku, mengingat mobilitas yang tinggi dalam kegiatannya.

29 Damien Dematra, Sejuta Hati Untuk Gus Dur............., 218

30 Salahuddin Wahid, "Gus Dur................, 34

31 Dalam hal ini, ada kesamaan dengan KH. A. Wahid Hasyim, karena hingga
Hanya saja, karena buku-buku yang diterbitkan itu dalam bentuk bunga rampai31, tanpa ada rekonstruksi dari Gus Dur sendiri, maka kesan ketidakutuhan bangunan pemikirannya menjadi tidak bisa dihindari. Tetapi itulah barangkali cerminan dari latar intelektual Gus Dur, yang bukan dari tradisi akademik sekolah modern, di mana setiap tulisan mesti terikat dengan suatu metodologi referensi formal.32

Berdasarkan data yang diperoleh dari berbagai sumber buku, seperti Jombang Kairo Jombang Chicago Sintesis Pemikiran Gus Dur dan Cak Nur dalam Pembaruan Islam di Indonesia serta data lain termasuk penelusuran pada kolektor buku penggemar Gus Dur dan pencarian memalui media internet, didapatkan di antara buku tulisannya adalah:

1. Kontroversi Pemikiran Islam di Indonesia

2. Hukum Islam di Indonesia: Pemikiran dan Praktik

3. Bungan Rampai Pesantren

4. Kiai Nyentrik Membela Pemerintah

5. Tabayun Gus Dur, Pribumisasi Islam, Hak Minoritas, Reformasi Kultur

6. Agama dan Kekerasan: Dari Anarkisme Politik ke Teologi Kekerasan

7. Gus Dur menjawab Perubahan Zaman

8. Membangun Demokrasi

9. Tuhan Tidak Perlu Dibela

10. Prisma Pemikiran Gus Dur

11. Menggerakkan Tradisi: Esai-esai Pesantren

12. Abdurrahaman Wahid Selama Lengser: Kumpulan Kolom dan Artikel

13. Islamku, Islam Anda, Islam Kita

14. Gus Dur Menjawab Kegelisahan Rakyat

15. Islam Kosmopolitan: Nilai-nilai Indonesia dan Transformasi Kebudayaan

16. Membaca Sejarah Nusantara: 25 Kolom Sejarah Gus Dur

17. Muslim Di Tengah Pergumulan

18. Mengurai Hubungan Agama dan Negara

Sedangkan buku yang isinya menulis tentang Gus Dur, yang ditulis oleh selain Gus Dur tidak

wafatnya, beliau tidak mempunyai tulisan dalam bentuk buku, tetapi berupa tulisan yang tersebar dalam berbagai media. Lihat Abu Bakar, Sejarah Hidup.........

32 Irwan Suhanda (editor), Gus Dur Santri....., xv-xvi 
kalah banyak jumlahnya. Terlebih setelah dia wafat hampir setiap bulan terbit buku tentang Gus Dur. Tetapi secara umum, buku-buku tersebut dapat dikelompokkan ke dalam beberapa kategori: sosial kemanusiaan, politik, hukum, agama, pendidikan dan pengajaran, biografi serta humoritasnya.

\section{Penghargaan dan Karir}

Berikut adalah penghargaan yang diperoleh oleh Gus Dur:

1. Tokoh tahun 1990, majalah Editor, tahun 1990

2. Ramon Magsaysay Award for Community Leadhership, Ramon Magsaysay Award Foundation, Philipina, tahun 1991

3. Islamic Missionary Award from the Government of Egypt, tahun 1991

4. Penghargaan Bina Ekatama, tahun 1994

5. Man of The Year 1998, majalah berita Independent, tahun 1998

6. Honorary Degree in Public Administration and Policy Issues from the University of Twente, tahun 2000

7. Gelar Doktor Kehormatan dari Universitas Jawaharlal Nehru, tahun 2000

8. Doctor Honoris Causa dalam bidang Philosophy in Law dari Universitas Thammasat Thaprachan Bangkok, Tailand

9. Doctor Honoris Causa dari Universitas Paris I (Pantheon Sorbonne) pada bidang ilmu hukum dan politik, ilmu ekonomi dan manajemen, dan ilmu humaniora, tahun 2000

10. Penghargaan Kepemimpinan Global (The Global Leadership Award) dari Columbia University, tahun 2000

11. Doctor Honoris Causa dari Asian Institute of Theology, Tailand, tahun 2000

33 "Biografi Abdurrahman Wahid", dalam http://www.andiestuff.com/biografiabdurrahman-wahid-gusdur/ diakses tanggal 13 Mei 2012
12. Ambassador for Peace, salah satu badan PBB, tahun 2001

13. Doctor Honoris Causa dari Universitas Sokka, Jepang, tahun 2002

14. Doctor Honoris Causa bidang hukum dari Konkuk University, Seoul, Korea Selatan, tahun 2003

15. Medals for Valor, sebuah penghargaan bagi personal yang gigih memperjuangkan pluralisme dan multikulturalisme, diberikan oleh Simon Wieshenthal Center (yayasan yang bergerak di bidang penegakan HAM dan toleransi antarumat beragama) Yew York, tahun 2009

16. Pengahargaan nama KH. Abdurrahman Wahid sebagai salah satu jurusan studi Agama di Temple University, Philadelphi, tahun 2009.33

Sementara, perjalanan karirnya adalah sebagai berikut:

1. Guru madrasah Mu'allimat, Jombang (19591963)

2. Dosen Universitas Hasyim Asy'ari, Jombang, (1972-1974)

3. Dekan Fakultas Ushuluddin Universitas Hasyim Asy'ari, Jobang (1972-1974)

4. Sekteratis Pesantren Tebuireng, Jombang (1974-1979)

5. Pengasuh Pondok Pesantren Ciganjur, Jakarta (1976-2009)

6. Ketua Tanfidziyah Pengurus Besar Nadhatul Ulama (1984-1989, 1989-1994, 1994-1999, dan 2000-2005)

7. MPR dari utusan golongan (1987-1992, 1999-2004)

8. Presiden RI (20 Oktober 1999-23 Juli 2001)

9. Ketua Umum Dewan Syuro PKB (20002005)

10. Ketua Umum Dewan Syuro PKB hasil Muktamar II, Semarang (2005-2010) 34

Corak Pemikiran

Setelah Gus Dur mempelajari Islam radikal, kemudian ia merasa tertarik untuk bergabung bahkan sempat aktif menjadi anggota kelompok Islam garis keras, Ikhwanul Muslimin. Dengan bergabung ke dalam kelompok ini, jelas sangat

\footnotetext{
34 Irwan Suhanda (editor), Gus Dur Santri....., xv-xvi
} 
memengaruhi pola berpikirnya yang cenderung mengarah pada pola berpikir liberal.35 Pengaruh-pengaruh liberalismenya yang terbentuk tidaklah sukar untuk diidentifikasi. Pertama, faktor keluarga. Di dalam keluarga dia dididik untuk bersikap terbuka dan mempertanyakan sesuatu secara intelektual. Kedua, ia dibesarkan di dunia sufistik Islam tradisional Indonesia.36 Dan ketiga, ia dipengaruhi oleh orientasi budaya masyarakat Indonesia modern yang mengarah pada pluralisme dan egalitarianisme. Akhirnya, ia sangat dipengaruhi oleh apa yang dibaca dan dipelajarinya karena keduanya memberikan kesempatan kepada dirinya untuk mencoba menyintesiskan pemikiran Barat modern dengan Islam.37

Ketika berada di Yogyakarta, ia sangat berterima kasih pada guru bahasa Inggrisnya yaitu ibu Rupiah yang melihat potensi membaca Gus Dur yang sangat tinggi untuk kemudian diberikan bacaan yang berhaluan kekiri-kirian, diantaranya adalah buku Das Kapital tulisan Karl Max dan beberapa buku penting lainnya. Kekayaan akan wawasan pengetahuan tersebut ternyata membukakan cakrawala berpikirnya, yang mendukung sikapnya yang cenderung bersifat liberal.

Akan tetapi Gus Dur meyakini akan kesempurnaan ajaran Islam, yang ditampilkan melalui sebuah ajaran universalisme Islam. Yaitu, lima buah jaminan dasar yang diberikan agama samawi terakhir ini kepada warga masyarakat, baik sebagai perorangan maupun sebagai kelompok. Kelima dasar tersebut tersebar dalam literartur hukum agama al-kutub al-fikihiyyah kuno, yaitu (1) jaminan dasar atas keselamatan fisik warga masyarakat dari tindakan badani di luar ketentuan hukum (hifdzu an-nafs), keselamatan keyakinan agama masingmasing tanpa ada paksaan untuk pindah agama (hifdzu ad-din), keselamatan

\footnotetext{
${ }^{35}$ Sebagai sebuah contoh, misalnya keberadaanya sebagai ketua Dewan Kesenian Jakarta (DKJ), hingga upayanya mengganti assalamu'alaikum dengan selamat pagi.

36 Berbeda dengan adik-adiknya yang lain, kecuali Hasyim Wahid (Gus Iim), Gus Dur lebih mendalami ajaran sufi, sehingga ketika masih berada di pesantren Tegalrejo Magelang, dia sering mengunjungi makam para wali di waktu tengah malam dan membaca bacaan-bacaan tertentu.
}

keluarga dan keturunan (hufdzu an-nasl), keselamatan harta benda dan milik pribadi dari gangguan atau penggusuran di luar prosedur hukum (hifdzu al-mal), dan keselamatan hak milik dan profesi (hifdzu al-aql). 38

Ke semua konsep pendidikan Gus Dur ini, sebenarnya sangat dipengaruhi oleh keyakinan dan paradigmanya, yakni demokrasi, inklusifisme agama, dan pembelaannya terhadap kaum lemah. Keyakinan-keyakinan ini terlihat jelas dari belantara pemikirannya yang terkodifikasi dalam karya-karyanya, semisal buku Tuhan Tak Perlu Dibela, Islamku, Islam Anda, Islam Kita, Islam Kosmopolitan, Mengurai Hubungan Agama dan Negara, Tabayun Gus Dur dan beberapa buku, artikel, atau karya-karyanya yang lain.

\section{KONSEP PENDIDIKAN ISLAM KH. ABDURRAHMAN WAHID}

\section{Hakikat Pendidikan Islam}

Secara ekspisit tidak pernah ditemukan konsepsi pendidikan Islam dalam satu rumusan istilah. Menurut Gus Dur, yang paling penting adalah bagaimana umat itu berlaku dan bersikap secara Islami. Tulisan tentang tarbiyah oleh Gus Dur tidak lebih sebagai reaksi dari munculnya penggunaaan istilah-istilah pada lembagalembaga pendidikan Islam dan idiom-idiom Islami lainnya.

Istilah tarbiyah yang berasal dari bahasa Arab tersebut menurut Gus Dur banyak digunakan sebagai istilah pendidikan. Di negara asalnya, kata tarbiyah mempunyai arti umum. Jika ingin menunjuk pada makna pendidikan secara khusus, maka akan ditambahkan kata lain, seperti al-tarbiyah al-siyasiyah, al-tarbiyah aldiniyah, dan lain sebagainya.

Namun kata tarbiyah itu di negara Indonesia mengalami penyempitan makna, sekalipun tetap bermakna pendidikan, tetapi dikhususkan untuk pendidikan agama Islam. Ini terbukti dari pemakaian istilah Fakultas Tarbiyah di Insitut Agama Islam Negeri (IAIN).39 Bahkan, tarbiyah yang sudah menjadi istilah tersendiri tersebut,

\footnotetext{
37 Greg Barton, Biografi Gus Dur, The Authorized Biography of Abdurrahman Wabid, (Yogyakarta: LKiS, cet IX, 2010), 135.

38 Agus Maftuh Abegebreil dan Ahmad Suaedy (ed), Islam Kosmopolitan Nilai-nilai Insonesia \& Tranformasi Kebudayaan, (Jakarta: The Wahid Institute, 2007), xxvii

39 Abdurrahman Wahid, Tuhan Tidak Perlu Dibela, (Yogyakarta, LKiS, cet. V, 2010), 61
} 
mengandung makna dan pengertian yang berbeda secara filosofis dengan kata sepadannya, yaitu ta'dib, ta'lim, dan tadris.

Akan tetapi menurut Gus Dur, kata tarbiyah yang telah dipersempit maknanya itu mencerminkan juga proses kompensatoris tersebut. Umat Islam merasakan, proses modernisasi pendidikan telah membawa ancaman bagi mereka, antara lain: revitalisasi nilai, memudarnya keyakinan, lunturnya keluhuran budi dan susila, dan seterusnya. Padahal nilai, keyakinan, susila, budi pekerti, dan nilai-nilai spiritualitas lainnya adalah penopang berlangsungnya ketaatan pada hukum agama, ketundukan pada kebenaran akidah dan kesediaan memelihara akhlak mulia.40

Simbolisasi kata pendidikan agama dengan istilah tarbiyah adalah merupakan bagian dari langkah strategis yang diambil untuk menentukan strategi konsentrasi daya dan kemampuan untuk membenahi wilayah yang cakupannya begitu luas medannya.

Agama menurut Gus Dur adalah sistem keyakinan yang menyediakan konsep tentang hakikat dan makna hidup, tetapi hal itu tidak terdapat pada segi-segi formalitas atau bentuk lahiriyah keagamaan. Ia berada di baliknya. Oleh karena itu, formalitas atau bentuk lahiriyah harus ditembus dan diseberangi. Kemampuan melampaui segi-segi itu niscaya akan berdampak pada tumbuhnya sikap-sikap religius individu atau pun masyarakat. Sehingga, pendidikan Islam sebagai perangkat luar harus mampu menyediakan perangkat berikut kerangkanya untuk membidani lahir dan tumbuhnya sikap-sikap religius tersebut.

Untuk melengkapi dirinya, pendidikan Islam membutuhkan alat bantu ilmu-ilmu

40 Ibid, 62

$41 \quad$ Multikulturalisme secara etimologis marak digunakan pada tahun 1950an di Kanada. Menurut Longer Oxford Dictionary istilah "multiculturalism" merupakan deviasi dari kata "multicultural". Kamus ini menyitir kalimat dari surat kabar Kanada, Montreal Times yang menggambarkan masyarakat Montreal sebagai masyarakat "multicultural dan multi-lingual". Lihat Choirul Mahfud, Pendidikan Multikultural, (Yogyakarta: Pustaka Pelajar, cet. I, 2006), 75. Multikulturalisme adalah sebuah filosofi- lain, sesuai dengan perkembangan jenis keilmuan yang lahir sebagai buah dari perkembangan filsafat ilmu. Sehingga pendidikan Islam terintegrasi dalam aneka macam keilmuan secara holistik. Jangkauannya pun sudah tidak lagi hanya pada wilayah pemahaman akan Islam, tetapi terapan akan nilai-nilai Islam itu berdasar pada kesadaran yang tulus, tanpa ada keterpaksaan dan tekanan.

Mengingat pendidikan adalah salah satu hak dasar yang dimiliki oleh setiap warga untuk mengembangkan potensi fitrah kemanusiaannya yang ada pada dirinya, maka pendidikan wajib mendapatkan porsi yang sama untuk dikembangkan, sejajar dengan potensi dan fitrah yang lain.

Konsep pendidikan yang ingin dikembangkan oleh Gus Dur ialah religious multiculturalism based education, yaitu konsep pendidikan yang didasarkan pada keyakinan keagamaan dan bertujuan untuk membimbing atau menghantarkan peserta didik menjadi manusia yang utuh, mandiri dan bebas dari belenggu penindasan. Dalam konsep ini, dia tampaknya tidak menolak akan potensi keberbedaan untuk selanjutnya ditindaklanjuti dalam sebuah konsep yang jelas dengan meletakkan heterogenitas tersebut sebagai bagian yang tidak terpisahkan dalam pendidikan itu sendiri.

Dari konsep tersebut, tersirat dengan jelas bahwa dia sebenarnya adalah peletak dasar konsep pendidikan multikultural.41 Pendidikan multikultural tersebut telah menjadi kebutuhan yang mendesak tidak saja bagi bangsa Indonesia yang memiliki khazanah pluralitas yang tinggi, tetapi juga masyarakat dunia yang mempunyai potensi dan karakter keberbedaan yang besar. 42

Di Indonesia misalnya, kesenjangan ekonomi, pemanfaatan sumber daya negeri yang tidak merata, tingkat pengangguran yang tinggi, konflik antar etnis, tawuran antar pelajar, pertikaian antar pendukung dalam pemilu, baik daerah maupun pusat, penistaan dan penodaan simbol-simbol agama dan kepercayaan, hingga

terkadang ditafsirkan sebagai ideologi yang menghendaki adanya persatuan dari berbagai kelompok kebudayaan dengan hak dan status sosial politik yang sama dalam masyarakat modern. Istilah multicultural juga sering digunakan untuk menggambarkan kesatuan berbagai etnis masyarakat yang berbeda dalam suatu negara. Lihat Babun Suharto, Pendidikan Multikultural dalam Pendidikan Islam Integrasi Konsep dan Aplikasi dalam Pendidikan, (Yogyakarta: Absolute Media, cet. I, 2010), 15

42 Abdurrahman Wahid, Tuhan 63 
penentuan awal Ramadhan dan awal Syawal, termasuk penentuan arah kiblat, serta beberapa fatwa Majlis Ulama Indonesia (MUI) yang seringkali berimplikasi pada masyarakat Indonesia yang plural, semuanya memiliki potensi keberbedaan dan potensi konflik jika tidak diiringi dengan sebuah pemahaman akan keberadaan perbedaan tersebut.43 Sehingga menghadirkan pendidikan yang berbasis multikultur adalah sebuah keniscayaan, bahkan sebuah kebutuhan mutlak.

Dalam konsepsi Gus Dur, pendidikan, dalam hal ini pendidikan Islam harus berbasis pada penghargaan dan penghormatan terhadap perbedaan masyarakat. Segala bentuk pendidikan dan kemampuan atas perjuangan masyarakat harus dihargai bersama, bahkan perlu untuk dikembangkan, terlebih di Indonesia yang memiliki tingkat pluralitas tinggi.

Konsepsi Gus Dur tersebut seperti yang diungkapkan oleh Mohammad Bakir, adalah ketika Gus Dur mencoba membuka wacana keberbedaan dalam pola bermazhab kepada para kiai, yang semula "Syafi'iyan" murni dan tidak boleh tercampur oleh pendapat selain mazhab Syafi'i, pelan-pelan mulai bergeser pola pikirnya untuk mengkaji kitab di luar mazhab Syafi'i.44

Selain itu, upaya Gus Dur untuk mengenalkan masalah aktual dengan cara pandang agama kepada para kiai merupakan bentuk riil dari usahanya untuk memadukan religiusitas agamawan dengan persoalan kebangsaan. Diantaranya adalah dinamika multikultural pluralitas bangsa Indonesia, untuk dicarikan jawabannya melalui pendidikan Islam. 45

\section{Tujuan Pendidikan Islam}

43 Lebih jelas lihat Malik Fadjar, Holistika Pemikiran Pendidikan Islam, (Jakarta: PT. Raja Grafindo Persada, 2005)

44 Mohammad Bakir, "Gus Dur dan Inklusivisme NU”, dalam Gus Dur Santri Par Excellence, Teladan Sang Guru Bangsa, Irwan Suhanda (ed), (Jakarta: PT. Kompas Media Nusantara, 2010), 48

45 Ibid, 49

46 Peresmian The Wahid Instutute diselenggarakan di Ballroom Hotel Four Seasons Jakarta, pada hari Selasa, 7 September 2004.

Lihat
Sementara, tujuan pendidikan Islam menurut Gus Dur, diantaranya dapat dipotret dari didirikannya The Wahid Institute, yaitu membangun pemikiran Islam moderat, yang mendorong terciptanya demokrasi, pluralisme agama-agama, multikulturalisme dan toleransi di kalangan kaum muslim Indonesia. Hal ini disampaikan oleh Yeny Wahid dalam acara peresmian The Wahid Institute.46

Menurut Yenny Wahid, salah satu program The Wahid Institute adalah mengampanyekan pemikiran Islam yang menghargai pluralitas dan demokrasi. Tujuan itu diaplikasikan melalui program pendidikan, dengan mendidik kiai-kiai muda yang ada di desa.47

Sebagai salah satu bukti adalah sebagaimana yang diungkapkan oleh Arifin Junaidi,48 sekitar awal tahun 1990-an hampir tiap hari Gus Dur menelpon kiai yang ada di daerah, baik untuk hanya sekedar menyapa atau berdiskusi akan suatu masalah.49 Ini menandakan tidak hanya upaya kedekatan secara emosional, tetapi lebih menunjukkan pada perhatian Gus Dur akan pentingnya peran kiai yang ada di desa-desa. Dan untuk memelihara kontinuitas tali estafet peranan tokoh dan kiai tersebut, tentu pendidikan adalah sarana yang efektif.

Gus Dur sadar akan nilai pluralitas yang ada di Indonesia, sehingga potensi tersebut dicoba untuk disinergikan dalam realitas kehidupan dengan bersendikan nilai-nilai Islam, melalui pembentukan dan penciptaan tokoh-tokoh yang mampu membumikan idealitas tersebut, khususnya para tokoh muda yang ada di desa. Para tokoh muda yang ada di desa ini adalah potensi yang juga memiliki kompetensi untuk memberikan kontribusi yang signifikan bagi pembangunan bangsa.

Di samping itu, para tokoh muda tersebut telah memiliki bekal yang memadai berupa pengetahuan agama dan pelatihan pembentukan akhlak di pesantren. Nilai moral inilah, merupakan nilai lebih yang penting untuk menjadi perhatian.

http://polhukam.kompasiana.com./2009/12/31/bi ografi-gus-dur-dan-keluarga/ diakses tanggal $30 \mathrm{Mei}$ 2012

$$
\begin{aligned}
& 47 \text { "Biografi Gus Dur dan Keluarga", } \\
& \text { http:// }
\end{aligned}
$$$$
\text { /2009/12/31/biografi-gus-dur-dan-keluarga/ }
$$

diakses tanggal 30 Mei 2012

48 Mantan orang dekat Gus Dur yang sempat menjabat sekteraris Dewan Syura Partai Kebangkitan Bangsa (PKB)

49 Mohammad Bakir, "Gus Dur dan Inklusivisme NU”, dalam Gus Dur Santri........, 49 
Ketika ditanya wartawan di Malaysia pada awal Nopember 1999 tentang hubungan agama dan negara, Gus Dur manyatakan bahwa agama adalah sebagai "akhlak" atau "etika", bukan ideologi yang digunakan untuk mengislamkan negara. Oleh karena itu, akhlak dan etika menjadi prioritas penting dalam kacamata Gus Dur untuk membentuk masyarakat madani yang tenteram, damai, dalam sebuah tata nilai yang dihormati bersama. Dan jika ditarik dalam domain pendidikan, pendidikan Islam dalam hal ini, perspektif Gus Dur tentang etika dan moral yang menjadi tujuan akhirnya.50

Bagi Gus Dur, seperti dikemukakan oleh Ali Masykur Musa,51 sebuah masyarakat Islam tidak perlu ada dalam sebuah negeri, termasuk Indonesia. Tetapi yang lebih penting adalah bagaimana nilai-nilai keislaman itu dapat diabsordir dalam konteks realitas kehidupan nyata. Tentu pendidikan Islam termasuk di dalamnya. 52

Urgensi pendidikan Islam terletak pada aplikasinya dalam tatanan kehidupan nyata, sehingga ruh pendidikan itu menjadi lebih penting daripada formalitas fisik yang nampak di luar. Menjadikan agama sebagai sumber inspirasi orang beragama dan bernegara adalah lebih penting sifatnya.

Hal tersebut senada dengan apa yang disampaikan oleh Ahmad Fachruddin, bahwa pemikiran Gus Dur termasuk pendidikan Islam bertujuan untuk merealisasikan nilai-nilai moral, kemanusiaan, kejujuran, keadilan, kesederhanaan serta demokrasi.53

Menurut Gus Dur, pendidikan etika dan moral saat ini seakan diabaikan. Sehingga

50 Ayu Sutarto, Indonesia di Mata Seorang Kiai NU Kesaksian Politik. KH. Abdul Muchit Muradi, (Jember: Jember University Press, 2010), 90

51 Ali Masykur Musa adalah mantan anggota Fraksi Partai Kebangkitan Bangsa (PKB) DPR RI dua periode (1999-2004 dan (2004-2009), pernah menjadi ketua umum DPP PKB versi Gus Dur, sehingga dia diasumsikan salah satu orang dekat Gus Dur. Sekarang menjadi anggota BPK pusat untuk masa tugas 2009-2014

52 Ali Masykur Musa, Pemikiran 88 banyak sarjana dengan berbagai gelar tapi tidak memiliki etika dan moral.54

Pentingnya akhlak ini sebenarnya terkait erat dengan misi yang diemban oleh nabi Muhammad SAW, yaitu untuk menyempurnakan akhlak.

Gus Dur berpendapat, penyempurnaan itu berjalan karena akhlak mulia yang sudah dirintis dan dijaga oleh para ulama ini akan mengalami proses klasifikasi, bukan dalam bentuk lahirnya, akan tetapi kualitasnya, karena akhlak itu sendiri akan dituntut semakin melebar wawasannya, semakin luas jangkauannya. 55

Ada empat sistem yang bisa menegakkan Indonesia di masa depan. Keempat sistem tersebut, menurut Gus Dur, pertama, adalah sistem politik, kedua, sistem ekonomi, ketiga, sistem pendidikan, dan keempat, adalah sistem etika/moral atau akhlak.

Keempat sistem tersebut memiliki peranan dan cakupan masing-masing. Yang perlu ditegaskan adalah bahwa di antara masing-masing sistem tersebut tidak dapat berjalan dengan sendirinya. Sistem politik yang kuat, membutuhkan bangunan yang di atasnya tertata ekonomi yang kokoh yang ditegakkan atas semangat moral dan etika yang luhur melalui pendidikan.56

Etika atau akhlak yang kita pahami selama ini harus dikembangkan sayapnya, dari yang hanya berbicara muru'ah saja yaitu sebagai tata karma, sebagai aturan main dan kesopanan, dilebarkan sayapnya dalam wajah yang lain, juga dalam isi yang lain, yakni menyangkut wawasan. Wawasan akhlakul karimah yang tidak hanya dipahami telah berbuat sopan apabila telah menjaga kesusilaan, sementara masalah masyarakat seperti kampung kumuh, orang miskin yang tidak dapat memenuhi kebutuhan pokok hidupnya, masih terdapat di tengah-

53 Ahmad Fachruddin, Gus Dur dari Pesantren ke Istana Negara, (Jakarta: Yayasan Gerakan Amaliah Siswa, 1999), 118

54 Abdurrahman Wahid, "Pendidikan Berbasis Masyarakat Harus Dihargai", dalam http://www.gusdur.net/Berita/Detail/?id=91/hl=id /Pendidikan Berbasis Masyarakat Harus Dihargai, diakses tanggal 05 Juni 2012

55 Abdurrahman Wahid, "Tugas Ulama Memperluas Wawasan AKhlak", dalam majalah Nahdatul Ulama, AULA, nomor 01/tahun XIII/Januari 1991/Jumadil Akhirah-Rajab 1411, 20 21

56 Abdurrahman Wahid, "Empat Sistem yang Bisa Tegakkean Masa Depan RI", dalam gusdur.net., diakses tanggal 05 Juni 2012 
tengah masyarakat.57 Sehingga akhlak yang substansinya adalah nilai luhur tersebut menurut pandangan Gus Dur sifatnya dinamis. Dinamisasi konsep akhlak itu secara otomatis memengaruhi tujuan pendidikan Islam itu sendiri, yakni etika atau akhlak yang dikembangkan dalam pola wawasan yang terintegrasi secara holistik dalam pendidikan itu sendiri.

Menurut Gus Dur, agama tidak hanya dijadikan tempat untuk mencari kenikmatan spiritual saja, akan tetapi agama harus dijadikan sebagai basis pergerakan dalam memperjuangkan kaum lemah. Oleh karena itu, pendidikan Islam harus mampu menangkap pesan moral agama tersebut, untuk kemudian mensinergikannya dengan tujuan pendidikan Islam itu sendiri.

Hal yang paling penting untuk dilakukan adalah dengan membuat kerangka pemahaman terhadap segala aspek kehidupan masyarakat, termasuk di dalamnya pendidikan berdasarkan pandangan agama. Yang lebih dibutuhkan adalah kerangka yang mampu menumbuhkan sikap jiwanya.58 Sebab dengan penciptaan pemahaman tersebut, maka agama akan menjadi sumber inspirasi begi kesadaran untuk mengaplikasikan nilai-nilai agama yang sifatnya universal tersebut.

Maka akan menjadi sebuah keniscayaan untuk berandai-andai sekiranya hal itu bisa terwujud, kejayaan Islam termasuk pendidikan Islam masa lalu akan membumi di masa sekarang dan akan datang.

\section{Kurikulum Pendidikan Islam}

Gus Dur sangat getol dalam membuka cakrawala pesantren. Sudah wajar jika pada 15 Desember tahun 2000 lalu, karena jasa-jasanya dalam mengembangkan demokrasi dan sistem pendidikan di Indonesia, terutama di pesantren, ia mendapatkan anugerah doktor kehormatan di bidang teknologi dan komunikasi oleh Akademika Institut Teknologi Asia (AIT), Bangkok, Thailand. Namun disayangkan, sangat sedikit orang yang mengetahui pembacaan Gus Dur

\footnotetext{
${ }^{57}$ Ibid

58 Abdurrahman Wahid, Prisma Pemikiran Gus Dur, (Yogyakarta: LKiS, 1999), 117
}

terhadap tradisi pesantren. Tampaknya, hitungan jari sudah cukup mengklasifikasikannya, tertama tentang pandangan-pandangannya tentang pesantren. Kita mungkin sudah tahu betul bahwa Gus Dur merupakan tonggak utama (penguripurip; Jawa) pesantren di negeri ini. Dengan jasajasa Gus Dur, pesantren menjadi lembaga pendidikan yang memiliki potensi plus.59

Pemikirannya yang pluralis, kontroversial, dan mempunyai pandangan yang jauh ke depan tidak bisa dielakkan mempunyai andil yang besar dalam pembangunan masyarakat di Indonesia, lebih-lebih pada sebuah institutsi pendidikan Islam yang memiliki akar sejarah yang berbedabeda.

Gus Dur dalam salah satu ceramahnya di Yayasan Wakaf Paramadina menawarkan ide universalisme dan kosmopotalisme peradaban Islam. Universalisme Islam ditunjukkan dalam ajaran kepedulian kepada unsur-unsur utama kemanusiaan yang diimbangi oleh kearifan yang muncul dari keterbukaan peradaban Islam. Menurutnya, salah satu yang dengan sempurna menampilkan universalisme Islam adalah lima buah jaminan dasar yang diberikan Islam, baik kepada perorangan maupun kelompok. Kelima jaminan dasar tersebut ialah (1) keselamatan fisik warga masyarakat dari tindakan badani di luar ketentuan hukum; (2) keselamatan keyakinan agama masing-masing tanpa ada paksaan untuk berpindah agama; (3) keselamatan keluarga dan keturunan; (4) keselamatan harta benda dan milik pribadi di luar prosedur hukum; dan (5) keselamatan profesi.

Kelima unsur hak asasi manusia itu, menurut Abdurrahman Wahid, tidak otomatis menjamin keselamatan umat manusia kalau tidak didukung kosmopolitanisme peradaban umat Islam. Kosmopolitanisme peradaban Islam itu muncul dalam sejumlah unsur dominan, misalnya hilangnya batasan etnis, kuatnya pluralitas budaya, dan heterogenitas politik, bahkan kosmopolitanisme Islam menampakkan diri dalam watak yang menakjubkan, yaitu kehidupan beragama yang eklektis berabad-abad. Hal ini antara lain tercermin dalam perdebatanperdebatan sengit selama empat abad pertama sejarah Islam di bidang teologi dan hukum agama yang di dalamnya perbedaan pendapat tetap memperoleh tempat yang semestinya.60

Gus Dur mengatakan bahwa kosmopolitanisme peradaban Islam mencapai titik optimalnya jika

59 http://infodiknas.com/paradigmabaru-pendidikan-islam-sebuah-upaya menuju pendidikan yang memberdayakan $-2 /$, diakses pada tanggal 16 Maret 2013

${ }^{60}$ Faisol, Gus Dur............., 106-107 
tercapai keseimbangan antara kecenderungan normatif kaum muslimin dan kebebasan berpikir semua warga masyarakat, termasuk mereka yang nonmuslim. Gus Dur menyebut sesuatu seperti itu sebagai kosmopolitanisme yang kreatif, yang memungkinkan pencarian sisi-sisi paling tidak masuk akal dari kebenaran yang ingin dicari dan ditemukan.

Apabila ditinjau ulang dari pemikiran Gus Dur yang plural, tentu saja tidak lepas dari situasi dan kondisi yang berkembang di negeri ini. Ketika melihat realitas sosial yang majemuk, dituntut sebuah pemikiran yang beragam pula, apalagi aspek pemikiran Gus Dur dalam hal pendidikan lebih banyak tercurah pada pondok pesantren sebagai salah satu institusi tua yang berkembang pertama kali di bangsa ini, yang tentu saja membutuhkan pemikiran yang cukup beragam.

Luar biasanya, dari semua itu pesantren mampu mendongkrak keilmuan umum. Nah, inilah yang ditekankan oleh Gus Dur dengan proses membumikan tradisi pesantren. Buku Menggerakkan Tradisi mengawali perjuangan Gus Dur dalam memopulerkan pesantren sebagai lembaga pendidikan yang multi-potensi, yakni keagamaan dan umum. Berkat tulisantulisannya tentang pesantren, di masa ia menjabat sebagai Presiden RI ke-4, pesantren menemukan kehidupan serta semangat baru dalam pemberdayaan masyarakat. Selain itu, kumpulankumpulan esai Gus Dur tentang pesantren mengajak kita pada perenungan dalam mengukur signifikansi dan menempatkan gagasan-gagasan di dalamnya sebagai suatu bagian dari pergumulan sejarah pemikiran pendidikan, terutama pesantren. Sebagaimana sudah galib diketahui oleh banyak orang, Orde Baru yang tampil pada tahun 1960-an bersama pembangunannya melahirkan konflik. Pesantren yang konvensional di masa itu beranggapan tidak dapat mengalami perubahan. Namun, itu hanya sejarah yang dapat ditampik oleh Gus Dur dengan gagasannya yang cukup gemilang, yakni proyeksi "modernisasi pesantren". Dalam artian, pesantren bukan lembaga pendidikan yang ketinggalan zaman.
Bahkan, kini sudah menjadi ikon pendidikan yang kreatif, mandiri, dan profesional. Hal ini dapat ditunjukkan dengan pendidikan karakter di pesantren, berupa akhlak, perilaku, norma, dan sopan santun. 61

Oleh sebab itu, kurikulum pendidikan Islam perspektif Gus Dur, haruslah sesuai dengan kondisi zaman, bahwa pendekatan yang harus dilakukan bersifat demokratis dan dialogis antara murid dan guru. Maka, tidak bisa dipungkiri pembelajaran aktif, kreatif, dan obyektif akan mengarahkan peserta didik mampu berpikir kritis dan selalu bertanya sepanjang hayat sehingga kurikulum tersebut mampu diharmonisasikan sesuai dengan konteks zaman yang ada di sekitarnya.62

Watak kosmopolitanisme dan universalisme yang tercermin dalam kenyataan tersebut digunakan Gus Dur untuk melakukan pengembangan terhadap teologi ahl al sunnah wa al-jamaah (Aswaja) dalam menghadapi berbagai perubahan dan tantangan masyarakat. Jika selama ini paham Aswaja, terutama di lingkungan NU hanya terkait dengan masalah teologi, fikih, dan tasawuf, bagi Gus Dur, pengenalan Aswaja harus diperluas cakupannya, yaitu meliputi dasar-dasar umum kehidupan bermasyarakat. Tanpa melakukan pengembangan ke arah itu, Aswaja sekedar menjadi muatan doktrin yang tidak mempunyai relevansi sosial. Dasar-dasar umum kehidupan bermasyarakat yang dimaksud Gus Dur adalah (1) pandangan manusia dan posisinya dalam kehidupan; (2) pandangan tentang ilmu pengetahuan dan teknologi; (3) pandangan ekonomis tentang pengaturan kehidupan bermasyarakat; (4) pandangan hubungan individu dan masyarakat; (5) pandangan tentang tradisi dan dinamisasinya melalui pranata hukum, pendidikan, politik, dan budaya; (6) pandangan tentang cara-cara pengembangan masyarakat; dan (7) pandangan tentang asas-asas internalisasi dan sosialisasi yang dapat dikembangkan dalam konteks doktrin formal yang dapat diterima saat ini.63

Dengan demikian, bahwasannya pemikiran tentang kurikulum pendidikan Islam sebagai proses pengembangan keilmuan dan teknologi, serta keterampilan itu, tidak hanya dalam cakupan yang kecil, tetapi lebih jauh lagi terhadap proses perkembangan dan perubahan dalam rangka kepentingan-kepentingan
61 KH. Abdurrahman Wahid, Menggerakkan Tradisi; Esay-esay Pesantren, (Yogyakarta: LKiS, 2010), 51-53

${ }^{62}$ Faisol, Gus Dur............., 111
63 KH. Abdurrahman Wahid, Islam Kosmopolitan; Nilai-nilai Indonesia dan Transformasi Kebudayaan, (Jakarta: The Wahid Institute, 2007), 9 
masyarakat di tengah lajunya moderniasi dan globalisasi.

\section{Bentuk dan Sistem Pendidikan Islam}

Konsep dan gagasan Gus Dur tentang sistem pendidikan secara jelas terlihat pada gagasannya tentang pembaharuan pesantren. Sebagaimana dituturkan oleh Muslim Abdurrahman, bahwa Gus Dur tiap kali bertemu dengan para intelektual pada disiplin ilmu apapun selalu mencoba untuk menyisipkan pesantren sebagai sebuah tawaran, baik secara keilmuan, peran dan fungsinya, maupun coraknya yang memiliki keunikan tersendiri.64

Mengenai pesantren, Gus Dur mencoba memotret model pendidikan pada masa awal, yaitu pesantren. Di mana pesantren mampu menjadi wadah dan menampung para siswa dari semua kalangan, baik dari kalangan keraton, maupun dari kelompok rakyat biasa. Dalam saat di mana semua mereka yang memiliki darah biru kebangsawanan dan mereka yang karena hubungannya dengan keraton dididik dalam lembaga pendidikan kekeratonan, pesantren menampung semua lapisan masyarakat yang tidak ditampung dalam lembaga pendidikan keraton. 65

Ini juga yang memberikan inspirasi untuk mewujudkan sebuah pendidikan yang berwatak akomodatif yang menampung siapa saja, karena pendidikan adalah menjadi hak setiap orang. Sehingga pesantren yang berkembang dewasa ini dengan segala kekurangan dan kelebihannya perlu untuk mendapatkan perhatian hingga menjadi sebuah lembaga yang ideal.

Menurutnya, semua aspek pendidikan pesantren mulai visi, misi, tujuan, kurikulum, manajeman dan kepemimpinannya harus diperbaiki dan sisesuaikan dengan perkembangan zaman era globalisasi. Pesantren harus membantu lulusannya agar dapat menjalani kehidupan sesuai dengan tuntutan zaman. Pesantren harus terlibat secara aktif dalam

64 Muslim Abdurrahman, "Dia Adalah Jendela Kepada Dunia", dalam Gus Dur Santri......, 22

65 Abdurrahman

Wahid,

Prisma.........., 111-112

66 Abuddin Nata, Tokoh-tokoh

Pembaharuan Pendidikan Isalm di Indonesia, (Jakarta: RajaGrafindo Persada, 2005 ), 360

67 Abkamul Fuqoba Solusi

Problematika Aktual Hukum Islam Keputusan memberdayakan masyarakat dan tampil sebagai agen perubahan sosial. Seiring dengan itu, kurikulum pesantren seharusnya tidak hanya berisi mata pelajaran agama saja, melainkan juga memuat mata pelajaran umum, ilmu pengetahuan dan teknologi serta keterampilan yang dibutuhkan oleh lapangan kerja.66

Meski demikian, menurut Gus Dur pesantren harus mempertahankan identitas dirinya sebagai penjaga tradisi keilmuan klasik, dalam arti tidak harus sepenuhnya larut dalam modernisasi, tetapi mengambil sesuatu yang dipandang bermanfaat dan positif untuk perkembangan. Dalam hal modernisasi ini ia berlandaskan pada maqalah sebagaimana berikut:

المحافظة على القديم الصالح و لأخذ بالجديد الأصلح

Artinya: "Memelihara dan melestarikan nilainilai lama yang masih relevan dan mengambil nilai-nilai baru yang lebih relevan.67

Selain itu, dalam melakukan modernisasi tersebut pesantren juga harus mampu melihat gejala sosial yang tumbuh di masyarakat, sehingga keberadaan pesantren dapat berperan sebagai pusat pengembangan masyarakat.

Dalam pengembangan dan modernisasi pesantren, Gus Dur menangkap adanya beberapa strategi yang dilakukan oleh beberapa pergerakan Islam; pertama, strategi sosial politik, kedua, strategi kebudayaan, dan ketiga, strategi sosial budaya.

Dalam strategi politik, ia menganggap perlu dan pentingnya menjelaskan butir-butir formalisasi pendidikan Islam ke dalam lembaga negara melalui usaha legal-formal yang terus menerus dilakukan. Lebih disukai dilakukan secara ekspisit melalui partai politik Islam. Untuk mengantisispasi perkembangan ini, masyarakat muslim harus mendidik dirinya dengan moral Islam yang benar dan menjadikan negara sebagai way of life bagi dirinya dan masyarakat sekitarnya.68 Dan pesantren menjadi bagian yang urgen di dalamnya, untuk memberikan kontribusi terhadap pembentukan watak dan karakter Islam yang menjadi sikap hidup dan perilaku dalam tatanan kehidupan.

Muktamar, Munar, Kombes Nabdhatul Ulama (19261999), (Surabaya: LTN NU Jatim dan Diantama Lembaga Studi dan Pengambangan Pesantren, 2005), 1

68 Abdurrahman Wahid, "Pondok

Peantren Masa Depan”, dalam Said Aqil Siradj et. al., Pesantren Masa Depan Wacana Pemberdayaan dan Transformasi Pesantren, (Bandung: Pustaka Hidayah, 1999), 22 
Sedangkan strategi kebudayaan, dimodifikasi melalui pengembangan cakrawala pandang, mempertebal ruang lingkup komitmen, dan memperdalam kesadaran atau kompleksitas lingkungan manusia dan kekuatan solidaritasnya dengan menghayati proses kejadian manusia tanpa memperhatikan ideologi, etnis, budaya, dan kepercayaan agama. Strategi ini menekankan dialog terbuka dengan semua ideologi dan pikiran filsafat dengan tujuan untuk mempertajam seluruh bentuk pengetahuan dan informasi semaksimal mungkin. Sikap ini, selain praksis, menghindarkan seluruh pendidikan Islam dan usaha-usaha formalisasi, mempersempit mereka dengan sikap ekslusif dan langkahlangkahnya, dan menghambat kebebasan untuk mengeluarkan pendapat dan pemikiran liberal yang diukur dengan strategi ini. Yang demikian ini adalah ideide sekuler, hanya bentuk pemerintahan yang cukup obyektif sajalah yang bisa menjamin kebebasannya.69

Adapun strategi sosial kebudayaan, melihat kebutuhan sosial untuk mengembakan framework kemasyarakatan dengan menggunakan prinsip-prinsip dan nilai-nilai Islam. Lembaga-lembaga yang dilahirkan dari strategi ini tidak menjadi institusi yang ekslusif, tetapi berupa institusi umum yang diterima oleh masyarakat. Memformalkan pendidikan Islam bukan merupakan proses transformasi, melainkan hanya membentuk suatu masyarakat di mana kaum muslim harus mengimplementasikan keyakinan, baik sebagai etika individu maupun etika sosial.70

Selanjutnya Gus Dur berpendapat, bahwa dalam melakukan modernisasi tersebut, pesantren harus mampu melihat gejala sosial yang tumbuh di masyarakat, sehingga keberadaan pesantren tersebut dapat berperan sebagai pusat pengembangan masyarakat. Upaya ke arah ini, menurut Gus Dur dapat

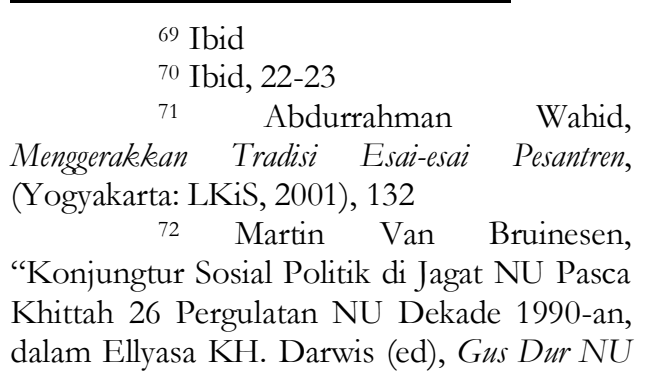

dilakukan dengan dua cara. Pertama, dengan cara mengarahkan semua perubahan yang dilakukan pada tujuan mengintegrasikan pesantren sebagai sistem pendidikan ke dalam pola umum pendidikan nasional yang membangun manusia yang kreatif. Kedua, dengan cara melakukan fungsi kemasyarakatan dalam kerangka menumbuhkan Lembaga Governmental Organization (LGO) menjadi Lembaga Non-Govermental Organization (NGO) yang kuat dan matang di pedesaan, sehingga mampu menjadi rekan yang sesungguhnya bagi pemerintah dalam upaya melakukan pembangunan sosial.71

Melihat gagasan dan pemikirannya yang demikian itu, tampak bahwa Gus Dur menginginkan agar pesantren tidak hanya berperan sebagai lembaga pendidikan keagamaan dalam arti yang selama ini berjalan, melainkan juga sebagai lembaga yang mampu memberikan sumbangan yang berarti serta membangun sistem nilai dan kerangka moral pada individu dan masyarakat. Dengan cara demikian, pesantren dapat menjadi lembaga yang mendidik manusia untuk bisa menjalani kehidupan dalam arti yang sesungguhnya. Gus Dur demikian yakin, bahwa pesantren memiliki potensi yang cukup kuat untuk mewujudkan masyarakat madani.72

Sebenarnya Gus Dur hendak mengatakan, bahwa peran pesantren tidak hanya sebagai lembaga pendidikan keagamaan, namun juga mampu memberikan sumbangsih yang berarti serta membangun sistem nilai dan kerangka moral pada individu dan masyarakat. Dengan cara demikian, pesantren dapat menjadi lembaga pendidikan yang mendidik manusia untuk bisa menjalani kehidupan dalam arti yang sesungguhnya.73 Bahkan, lebih jauh pesantren dapat juga memelopori perubahan sosial dengan caranya sendiri. Ia tidak hanya sekedar menjaring informasi, tetapi juga harus mampu menawarkan agenda perubahan yang dianggapnya sesuai dengan kebutuhan nyata masyarakat yang dipimpinnya. 74

Berdasarkan pada gagasannya, Gus Dur menginginkan agar peserta didik yang belajar di pesantren adalah peserta didik yang memiliki ilmu agama yang kuat dan sekaligus juga

dan Masyarakat Sipil, (Yogyakarta: LKiS, 1994), 77-78 73 Abuddin Nata, Tokoh-tokoh

Pembaharuan............., 351-352

${ }^{74}$ Abdurrahman Wahid, "Benarkah Kiai Membawa Perubahan Sosial" Sebuah Pengantar, dalam Hiroko Horikhosi, A Traditional Leader in a Time of Change: The Jijaji and Ulama in West Java, terj. Umar Basalim dan Andi Muarly, Kiai dan Perubahan Sosial, (Jakarta: P\#M, 1987), xvii 
memiliki ilmu umum yang kuat secara seimbang. Gus Dur menginginkan, agar di samping mencetak ahli ilmu agama Islam, pesantren juga mampu mencetak orang yang memiliki keahlian dalam ilmu pengetahuan dan teknologi, seperti ilmu komputer, fisika, pertanian, perkebunan, dan sebagainya. 75

Menurut Gus Dur, kurikulum sebagian pesantren beberapa tahun yang lalu cenderung menunjukkan pola yang stagnan. Setidaknya, stagnasi kurikulum pesantren dapat disimpulkan sebagai berikut: (a) tujuan kurikulum pesantren adalah untuk mencetak ulama atau ahli agama semata; (b) struktur dasar kurikulum pesantren adalah pengajaran pengetahuan agama dalam segenap tingkatannya dan pemberian pendidikan dalam bentuk bimbingan kepada santri; dan (c) secara keseluruhan kurikulum yang ada berwatak lentur, yaitu setiap santri berkesempatan menyusun kurikulumnya sendiri.76

Padahal, tidak semua santri yang belajar di pesantren dapat dicetak menjadi ahli agama atau ulama. Oleh karena itu, pesantren harus mulai mengadopsi kurikulum baru dari luar, yaitu kurikulum pengetahuan umum yang bertujuan untuk mencetak profesional yang religious.

Atas dasar di atas, Gus Dur menginginkan adanya perubahan pada kurikulum pesantren. Menurutnya, kurikulum pesantren selain harus kontekstual dengan kebutuhan zaman juga harus mampu merangsang daya intelektual-kritis anak didik. Terkait yang terakhir ini, antara lain dengan melebarkan pembahasan fikih antar mazhab. Begitu juga konsepsi tentang tasawuf penting untuk dirumuskan kembali, yang tidak harus berarti seorang mutashowwif selalu memiliki keterikatan moral dan keterlibatan dengan gerakan tarekat, tetapi penerapan akhlak tasawuf yang menjadi prioritas, serta pengembangan watak kemandirian pesantren yang merupakan akses positif dari pemahaman dan penghayatan pemikiran yang serba normatif yang bersumber dari orientasi fikih.77
Gus Dur juga menekankan pentingnya menghilangkan dikotomi antara ilmu agama dan ilmu umum, dengan catatan penguasaan ilmu agama harus diberi porsi yang cukup besar dalam kurikulum pesantren tersebut. Porsi tersebut dapat diberikan dalam ukuran besar secara kualitatif dan bukan dari segi kuantitif. Dengan kata lain, modernisasi kurikulum pesantren harus tetap berada pada jati dirinya, karena dengan cara demikian itulah, dunia pesantren tidak akan kehilangan jati dirinya. Namun demikian, semua itu pada akhirnya kembali kepada kemauan pengelolanya. 78

\section{KESIMPULAN}

Konsep pendidikan yang dikembangkan oleh Gus Dur ialah religious multiculturalism based education, yaitu konsep pendidikan yang didasarkan pada keyakinan keagamaan dan bertujuan untuk membimbing atau menghantarkan peserta didik menjadi manusia yang utuh, mandiri dan bebas dari belenggu penindasan. Dalam konsep ini, dia tampaknya tidak menolak akan potensi keberbedaan untuk selanjutnya ditindaklanjuti dalam sebuah konsep yang jelas dengan meletakkan heterogenitas tersebut sebagai bagian yang tidak terpisahkan dalam pendidikan itu sendiri.

Implikasi konsep pendidikan Gus Dur terhadap pengembangan pendidikan Islam di Indonesia adalah upaya untuk melihat realitas keberagamaan yang dimiliki oleh tiap bangsa Indonesia, dengan memberikan ruang bagi berkembangnya wawasan pluralisme dan multikulturalisme, terutama dalam proses pendidikan, sehingga pendidikan multikultural yang berbasis pada religiusitas (religious multiculturalism based education) yang mencermintan watak Islam yang utuh sebagai agama yang rahmatan li al-alamin, yang menjujung tinggi profesionalisme harus mensinergikan unsur-unsur modernisasi dengan nilai-nilai Islam dalam pendekatan multidisipliner guna menuju pendidikan yang integratif, bahkan terintegrasi secara holistik dalam kurikulum nasional.

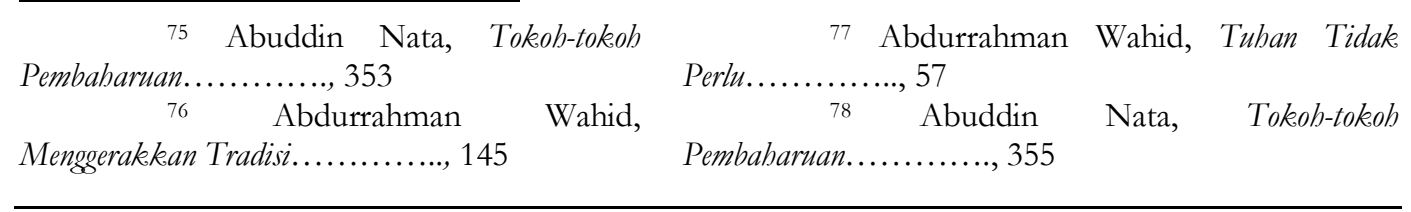




\section{DAFTAR BACAAN}

Fadjar, A. Malik, Holistika Pemikiran Pendidikan, (Jakarta: RajaGrafindo Persada, 2005)

Asrohah, Hanun, Sejarah Pendidikan Islam, (Jakarta: Logos Wacana Ilmu, 2001)

Zuhairini, dkk, Filsafat Pendidikan Islam, (Jakarta: Bumi Aksara, cet. IV, 2008)

Nata, Abuddin, Tokoh-tokoh Pembaruan Pendidikan Islam di Indonesia, (Jakarta: RajaGrafindo Persada, 2005)

Wahid, Abdurrahman, Prisma Pemikiran Gus Dur, (Yogyakarta: LKiS, 2010)

UU RI nomor 20 tahun 2003 tentang Sistem Pendidikan Nasional, dalam Kumpulan Undang-Undang dan Peraturan Pemerintah RI Tentang Pendidikan, (Jakarta: Direktorat Jenderal Pendidikan Islam Departemen Agama RI, 2007)

Barton, Greg, Biografi Gus Dur, The Authorized Biography of Abdurrahman Wahid, (Yogyakarta: LKiS, cet IX, 2010)

Fearly, Greg, Ijtihad Politik Ulama, Sejarah NU 1952-1967, (Yogyakarta: LKiS, 1998)

Suhanda, Irwan (editor), Gus Dur Santri Par Excellence Teladan Sang Guru Bangsa, (Jakarta: PT Kompas Media Nusantara, 2010)

Dematra, Damien, Sejuta Hati Untuk Gus Dur Sebuah Novel dan Memorial, (Jakarta: Gramedia Pustaka Utama, 2010)

Mahfud MD., Setahun Bersama Gus Dur, Kenangan Menjadi Menteri di Saat Sulit, (Jakarta: Murai Kencana, 2010)

"Biografi Abdurrahman Wahid", dalam http://www.andiestuff.com/biografiabdurrahman-wahid-gusdur

Abegebreil, Agus Maftuh dan Ahmad Suaedy (ed), Islam Kosmopolitan Nilainilai Insonesia \& Tranformasi Kebudayaan, (Jakarta: The Wahid Institute, 2007)

Wahid, Abdurrahman, Tuhan Tidak Perlu Dibela, (Yogyakarta, LKiS, cet. V, 2010)

Suharto, Babun, Pendidikan Multikultural dalam Pendidikan Islam Integrasi Konsep dan Aplikasi dalam Pendidikan,
(Yogyakarta: Absolute Media, cet. I, 2010)

Fadjar, A. Malik, Holistika Pemikiran Pendidikan Islam, (Jakarta: PT. Raja Grafindo Persada, 2005)Lihat

http://polhukam.kompasiana.com./2009/1

2/31/biografi-gus-dur-dan-keluarga "Biografi Gus Dur dan Keluarga", http:// polhukam.kompasiana.com.

/2009/12/31/biografi-gus-dur-dan-keluarga

Sutarto, Ayu, Indonesia di Mata Seorang Kiai NU Kesaksian Politik KH. Abdul Muchit Muzadi, (Jember: Jember University Press, 2010)

Fachruddin, Ahmad, Gus Dur dari Pesantren ke Istana Negara, (Jakarta: Yayasan Gerakan Amaliah Siswa, 1999)

Wahid, Abdurrahman, "Pendidikan Berbasis Masyarakat Harus Dihargai", dalam http://www.gusdur.net/Berita/Detail/?id=9 $1 / \mathrm{hl}=\mathrm{id} /$ Pendidikan Berbasis Masyarakat Harus Dihargai

Wahid, Abdurrahman, "Tugas Ulama Memperluas Wawasan AKhlak", dalam majalah Nahdatul Ulama, AULA, nomor 01/tahun XIII/Januari 1991/Jumadil Akhirah-Rajab 1411

Wahid, Abdurrahman, "Empat Sistem yang Bisa Tegakkan Masa Depan RI", dalam gusdur.net.

Wahid, Abdurrahman, Prisma Pemikiran Gus Dur, (Yogyakarta: LKiS, 1999)

http://infodiknas.com/paradigma-barupendidikan-islam-sebuah-upaya menuju pendidikan yang memberdayakan -2/

Faisol, Gus Dur dan Pendidikan Islam Upaya Mengembalikan Esensi Pendidikan di Era Global, (Yogyakarta: Ar-Ruzz Media, 2011)

Wahid, Abdurrahman, Menggerakkan Tradisi; Esay-esay Pesantren, (Yogyakarta: LKiS, 2010)

Wahid, Abdurrahman, Islam Kosmopolitan; Nilainilai Indonesia dan Transformasi Kebudayaan, (Jakarta: The Wahid Institute, 2007)

Ahkamul Fuqoha Solusi Problematika Aktual Hukum Islam Keputusan Muktamar, Munar, Kombes Nahdhatul Ulama (1926-1999), (Surabaya: LTN NU Jatim dan Diantama Lembaga Studi dan Pengambangan Pesantren, 2005)

Siradj, Said Aqil et. al., Pesantren Masa Depan Wacana Pemberdayaan dan Transformasi Pesantren, (Bandung: Pustaka Hidayah, 1999)

Darwis, Ellyasa KH. (ed), Gus Dur NU dan Masyarakat Sipil, (Yogyakarta: LKiS, 1994)

Horikhosi Hiroko, A Traditional Leader in a Time of Change: The Jijaji and Ulama in West Java, 
terj. Umar Basalim dan Andi Muarly, Kiai dan Perubahan Sosial, (Jakarta: P3M, 1987)

\section{DAFTAR PUSTAKA}

Abegebreil, Agus Maftuh dan Ahmad Suaedy (ed), Islam Kosmopolitan Nilai-nilai Insonesia \& Tranformasi Kebudayaan, (Jakarta: The Wahid Institute, 2007)

Asrohah, Hanun, Sejarah Pendidikan Islam, (Jakarta: Logos Wacana Ilmu, 2001)

Barton, Greg, Biografi Gus Dur, The Authorized Biography of Abdurrahman Wahid, (Yogyakarta: LKiS, cet IX, 2010)

Darwis, Ellyasa KH. (ed), Gus Dur NU dan Masyarakat Sipil, (Yogyakarta: LKiS, 1994)

Dematra, Damien, Sejuta Hati Untuk Gus Dur Sebuah Novel dan Memorial, (Jakarta: Gramedia Pustaka Utama, 2010)

Fachruddin, Ahmad, Gus Dur dari Pesantren ke Istana Negara, (Jakarta: Yayasan Gerakan Amaliah Siswa, 1999)

Fadjar, A. Malik, Holistika Pemikiran Pendidikan Islam, (Jakarta: PT. Raja Grafindo Persada, 2005)

Fadjar, A. Malik, Holistika Pemikiran Pendidikan, (Jakarta: RajaGrafindo Persada, 2005)

Faisol, Gus Dur dan Pendidikan Islam Upaya Mengembalikan Esensi Pendidikan di Era Global, (Yogyakarta: Ar-Ruzz Media, 2011)

Fearly, Greg, Ijtihad Politik Ulama, Sejarah NU 1952-1967, (Yogyakarta: LKiS, 1998)

Horikhosi Hiroko, A Traditional Leader in a Time of Change: The Jijaji and Ulama in West Java, terj. Umar Basalim dan Andi Muarly, Kiai dan Perubahan Sosial, (Jakarta: P3M, 1987)

http://www.andiestuff.com/biografiabdurrahman-wahid-gusdur

http:// polhukam.kompasiana.com. /2009/12/31/biografi-gus-dur-dankeluarga http://infodiknas.com/paradigma-baru-

pendidikan-islam-sebuah-upaya menuju

pendidikan yang memberdayakan -2/

http://polhukam.kompasiana.com./2009/12/3 1/biografi-gus-dur-dan-keluarga

Mahfud MD., Setahun Bersama Gus Dur, Kenangan Menjadi Menteri di Saat Sulit, (Jakarta: Murai Kencana, 2010)

Nata, Abuddin, Tokoh-tokoh Pembaruan Pendidikan Islam di Indonesia, (Jakarta: RajaGrafindo Persada, 2005)

Siradj, Said Aqil et. al., Pesantren Masa Depan Wacana Pemberdayaan dan Transformasi Pesantren, (Bandung: Pustaka Hidayah, 1999)

Suhanda, Irwan (editor), Gus Dur Santri Par Excellence Teladan Sang Guru Bangsa, (Jakarta: PT Kompas Media Nusantara, 2010)

Suharto, Babun, Pendidikan Multikultural dalam Pendidikan Islam Integrasi Konsep dan Aplikasi dalam Pendidikan, (Yogyakarta: Absolute Media, cet. I, 2010)

Sutarto, Ayu, Indonesia di Mata Seorang Kiai NU Kesaksian Politik KH. Abdul Muchit Muzadi, (Jember: Jember University Press, 2010)

UU RI nomor 20 tahun 2003 tentang Sistem Pendidikan Nasional, dalam Kumpulan Undang-Undang dan Peraturan Pemerintah RI Tentang Pendidikan, (Jakarta: Direktorat Jenderal Pendidikan Islam Departemen Agama RI, 2007)

Wahid, Abdurrahman, "Empat Sistem yang Bisa Tegakkan Masa Depan RI", dalam gusdur.net.

"Pendidikan Berbasis Masyarakat Harus Dihargai", dalam http://www.gusdur.net/Berita/Detail/?id=9 $1 / \mathrm{hl}=\mathrm{id} /$ Pendidikan_Berbasis_Masyarakat Harus_Dihargai

"Tugas Ulama Memperluas Wawasan AKhlak", dalam majalah Nahdatul Ulama, AULA, nomor 01/tahun XIII/ Januari 1991/Jumadil Akhirah-Rajab 1411

-------, Islam Kosmopolitan; Nilai-nilai Indonesia dan Transformasi Kebudayaan, (Jakarta: The Wahid Institute, 2007) Menggerakkan Tradisi; Esay-esay Pesantren, (Yogyakarta: LKiS, 2010)

(Yogyakarta: LKiS, 1999) 
--------------, Prisma Pemikiran Gus Dur, (Yogyakarta: LKiS, 2010)

----------, Tuhan Tidak Perlu Dibela, (Yogyakarta, LKiS, cet. V, 2010)

Zuhairini, dkk, Filsafat Pendidikan Islam, (Jakarta: Bumi Aksara, cet. IV, 2008) 